\title{
Pengaruh Ukuran Perusahaan,Net Profit Margin,Likuiditas,Profitabilitas Dan Finance Leverage Terhadap Perataan Laba Pada Perusahaan Manufaktur Industri Dasar Dan Kimia Yang Terdaftar Di Bei Tahun 2017-2018
}

\author{
Melin Dwi Pertiwi ${ }^{1}$, Nurfaizah ${ }^{2}$, Dirvi Surya Abbas ${ }^{3}$ \\ Universitas Muhammadiyah Tangerang ${ }^{1,2,3}$ \\ Email : melindwip@gmail.com,nfaizah900@gmail.com
}

\begin{abstract}
Abstrak: Laporan keuangan sering terpusat pada informasi laba tanpa memperhatikan prosedur yang digunakan untuk menghasilkan informasi laba usaha. Hal tersebut mendorong maanajemen untuk melakukan tindakan menejemen laba yaitu dengan melakukan perataan laba. Perataan laba adalah sebuah praktik dengan menggunakan teknik atau cara akuntansi untuk mengurangi ketidak tetapan laba bersih selama beberapa periode waktu. Tujuan penelitian ini adalah untuk mengetahui pengaruh SIZE, NPM, LIKUIDITAS, PROFITABILITAS dan FINANCIAL LEVERAGE terhadap praktik perataan laba (IS) pada badan usaha manufaktur yang terdapat di BEI periode 20172018.
\end{abstract}

Kata kunci: size, npm, likuiditas, profitabilitas, financial leverage, perataan laba.

Laporan keuangan adalah suatu penyajian sistematis dari posisi keuangan dan kinerja keuangan suatu entitas. Tujuan laporan keuangan adalah untuk memberikan informasi mengenai posisi keuangan, dan arus kas entitas yang bermanfaat bagi sebagian besar pengguna laporan keuangan dalam pembuatan keputusan ekonomik. Laporan keuangan juga menunjukkan hasil pertanggungjawaban manajemen atas sumber daya yang dipercayakan kepada mereka (Ikatan Akuntan Indonesia, 2015:1.3).

Perataan laba adalah upaya menguatkan laba dimana tidak banyak variance dari satu periode ke periode lain, sehingga dinilai sebagai prestasi baik. Tindakan manajemen dalam melakukan tindakan perataan laba pada perusahaan manufaktur didorong oleh kurangnya pengelolaan terhadap persediaan barang yang diproduksi serta minimnya pengawasan dan pengendalian berkaitan dengan aset-aset yang dimiliki. Perencanaan produksi pada perusahaan manufaktur juga menjadi dorongan dalam melakukan tindakan perataan laba.

Namun ada beberapa factor yang mempengaruhi dalam praktik penelitian ini. Faktor yang pertama ukuran perusahaan adalah makin besar,makin banyak alternative pembelanjaan sumber daya yang dapat di pilih,dan utang yang di milikinya cenderung makin besar. Hal ini sesuai dengan penelitian Sindi Retno Noviana, Etna Nur Afri Yuyetta,2012, Wildham Bestivano,2013, Kris Brantas Abiprayu, Irene Rini Demi Pangestuti,2011, Herni dan Yulius Kurnia Susanto,2008, Eko Budi Santoso,Sherly Novia Salim,2012, yang menyatakan bahwa ukuran perusahaan berpengaruh positif terhadap perataan laba. 
Faktor yang kedua net profit margin ,besar kecilnya npm tergantung oleh besar kecilnya laba yang di peroleh sehingga perusahaan cenderung untuk melakukan perataan laba. Hal ini sesuai dengan penelitian Sindi Retno Noviana, Etna Nur Afri Yuyetta,2012, Kris Brantas Abiprayu,Irene Rini Demi Pangestuti,2011, yang menyatakan hasil penelitian berpengaruh terhadap perataan laba, namun dalam penelitian I Nyoman Ari Widana Dan Gerianta Wirawan yasa 2013 menyatakan hasil penelitian tidak berpengaruh terhadap perataan laba. Berbeda dengan hasil penelitian Eko Budi Santoso,Sherly Novia Salim,2012 menyatakan hasil penelitian berpengaruh negative terhadap perataan laba.

Faktor yang ketiga likuiditas adalah bentuk komitmen dari pemegang saham untuk mendelegasikan pengendalian dengan tingkat tertentu kepada para manajer. Seperti dalam hasil penelitian Adi Utomo,Wisnu Prasetyo,MA Wahyono,2018 menyatakan hasil penelitian berpengaruh terhadap perataan laba,namun bertentangan dengan hasil penelitian Herni dan Yulius Kurnia Susanto,2008 menyatakan bahwa hasil penelitian berpengaruh negative terhadap perataan laba sedangkan dalam hasil penelitian Lusy Rahma Sari,2014 tidak berpengaruh terhadap perataan laba.

Faktor yang keempat adalah profitabilitas,praktik perataan laba cenderung dilakukan oleh perusahaan yang profitabilitasnya rendah dan dalam keadaan berisiko,karena ingin memperlihatkan bahwa laporan laba rugi lebih baik dan tingkat fluktuasi tidak terlalu tinggi,sehingga dapat menarik investor. Hal ini sesuai dengan penelitian Herni dan Yulius Kurnia Susanto,2008 menyatakan hasil penelitian bahwa profitabilitas berpengaruh negative terhadap perataan laba,sedangkan penelitian Eko Budi Santoso,Sherly Novia Salim,2012 menyatakan hasil penelitian profitabilitas tidak berpengaruh terhadap perataan laba.

Faktor yang kelima financial leverage,sebagai penggunaan aktiva untuk membayar beban tetap. Biasanya seorang kreditur tertarik pada perusahaan yang memiliki tingkat leverage yang rendah dan mengahasilkan leverage positif,sebab kreditur memerlukan jaminan atas dana yang di pinjamkan. Hal ini sesuai dengan penelitian I Nyoman Ari Widana Dan Gerianta Wirawan yasa 2013, Adi Utomo,Wisnu Prasetyo,MA Wahyono,2018, Wildham Bestivano,2013 menyatakan hasil penelitian financial leverage tidak berpengaruh terhadap perataan laba.

\section{METODE}

Populasi pada penelitian ini adalah perusahaan non-finansial yang tercatat di Bursa Efek Indonesia (BEI). Data laporan keuangan diperoleh dari www.idx.co.id, Periode pengamatan yang dijadikan objek penelitian ini adalah tahun 2017 dan 2018. Data yang digunakan adalah tahun 2017 sampai dengan 2018. Pemilihan sampel dalam penelitian ini menggunakan metode purposive sampling. Dengan metode purposive sampling ini, sampel dipilih berdasarkan kesesuaian kriteria pemilihan yang ditentukan. 
Perataan laba sebagai variabel dependen dalam penelitian ini di ukur dengan menggunakan skala nominal sebagai ukuranya yaitu perusahaan yang melakukan perataan laba di beri nilai 1,sedangkan perusahaan yang bukan perataan laba di beri nilai 0 . Tindakan pertaan laba di uji dengan menggunakan indeks eckel (1981), Eckel menggunakan Coefficient Variation (CV) variabel laba dan penjualan bersih. Indeks Eckel dapat di hitung dengan rumus sebagai berikut :

Indeks perataan laba : $\mathrm{CV} \Delta \mathrm{I} / \mathrm{CV} \Delta \mathrm{S}$

Dimana:

$\Delta \mathrm{l}:$ Perubahan laba dalam suatu periode

$\Delta S$ : Perubahan penjualan dalam suatu periode

CV: Koefisien variasi dari variabel yaitu standar deviasi dibagi dengan nilai yang di harapkan

Apabila CV $\Delta \mathrm{I}>\mathrm{CV} \Delta \mathrm{S}$, maka perusahaan tidak di golongkan sebagai perusahaan yang melakukan tindakan perataan laba.

CV $\Delta \mathrm{l}$ : Koefisien variasi untuk perubahan laba

CV $\Delta S$ : Koefisien variasi untuk perubahan penjualan.

CV $\Delta$ I dan CV $\Delta$ S dapat di hitung sebagai berikut:

$\mathrm{CV} \Delta \mathrm{l}$ atau $\mathrm{CV} \Delta \mathrm{S}=$ variance/(Expected value $)$

Atau

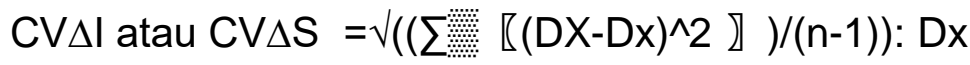

Dimana

DX : Perubahan laba (I) atau penjualan (S)

Dx : Rata-rata perubahan laba (I) atau penjualan / pendapatan (S)

$\mathrm{N} \quad$ : Banyaknya tahun yang di amati

Ukuran perusahaan adalah suatu skala dimana perusahaan diklasifikasikan menurut besar kecilnya berdasarkan pada total aktiva suatu perusahaan, semakin besar total aktiva maka semakin besar pula ukuran perusahaan tersebut.Sebaliknya jika perusahaan tergolong klasifikasi kecil maka semakin kecil pula perusahaan mendapat perhatian, sehingga manajer dapat leluasa melakukan praktik perataan laba.

SIZE = LN(Total Aktiva)

Net profit margin merupakan rasio profitabilitas untuk menilai persentase laba bersih yang didapat setelah dikurangi pajak terhadap pendapatan yang diperoleh dari penjualan. Rumus untuk mencari NPM adalah sebagai berikut:

$\mathrm{NPM}=\mathrm{EAT} /($ PENJUALAN BERSIH)

Likuiditas merupakan kemampuan perusahaan dalam memenuhi kewajiban untuk membayar utang jangka pendeknya yang harus segera dibayar dengan menggunakan harta lancar seperti utang usaha, utang deviden dan lain lain. Rumus untuk mencari $C R$ adalah:

$\mathrm{CR}=($ AKTIVA LANCAR $) /($ HUTANG LANCAR $)$ 
Profitabilitas atau rentabilitas adalah kemampuan perusahaan untuk menghasilkan laba selama periode tertentu. Salah satu cara mengukur profitabilitas pada suatu perusahaan menggunakan rasio Return On Asset (ROA). ROA adalah kemampuan modal yang diinvestasikan dalam keseluruhan aktiva untuk menghasilkan keuntungan neto. Keuntungan neto yang dimaksudkan adalah laba bersih setelah pajak. Apabila ROA diformulasikan dalam rumus menjadi:

$\mathrm{ROA}=($ Laba Setelah pajak $) /($ Total aset $)$

Financial leverage timbul karena adanya kewajiban-kewajiban keuangan yang sifatnya tetap yang harus dikeluarkan perusahaan. Kewajiban-kewajiban keuangan yang tetap ini tidaklah berubah dengan adanya perubahan tingkat EBIT dan harus dibayar tanpamelihat sebesar apapun tingkat EBIT yang dicapai oleh perusahaan. Perusahaan yang menggunakan dana dengan beban tetap dikatakan menghasilkan leverage yang menguntungkan (favorable financial leverage) atau efek yang positif jika pendapatan yang diterima dari penggunaan dana tersebut lebih besar daripada beban tetap dari penggunaan dana itu.Adapun perhitungan debt to equityratio menurut Husnan (1998) yaitu :

$\mathrm{DER}=($ Total Hutang $\times 100 \%) /($ Modal Sendiri $)$

\section{HASIL}

Nilai $\mathrm{t}$ - statistic ukuran perusahaan (size) sebesar 3.759568, sementara $t$ tabel dengan tingkat $\mathfrak{a}=5 \%$, df $(n-k)=30$ di dapat nilai $t-$ tabel sebesar 2.04227, Dengan demikian t - statistic SIZE (3.759568) > t tabel (2.04227) dan nilai prob. $0.00053<0.05$. Maka dapat disimpulkan bahwa variabel ukuran perusahaan (SIZE) dalam penelitian ini memiliki pengaruh terhadap perataan laba (income smoothing). Nilai koefisien regresi variabel SIZE sebesar - 0.053956 hal ini menggambarkan bahwa variabel SIZE berpengaruh negative terhadap IS.

Nilai $\mathrm{t}$ - statistic NPM sebesar 2.958619 , sementara t-tabel dengan tingkat $\mathfrak{a}=5 \%$ df $(n-k)=30$ didapat nilai t tabel sebesar 2.04227. Dengan demikian t-statistik NPM (-2.958619) < t tabel (2.04227) dan nilai prob. $0.0060<0.05$ maka dapat maka dapat disimpulkan bahwa variabel NPM dalam penelitian ini memiliki pengaruh terhadap IS.

Nilai t statistic CR sebesar 1.553788 sementara t tabel dengan tingkat $a=5 \%$ df $(n-k)=30$ di dapat nilai t tabel sebesar 2.04227. Dengan demikian $\mathrm{t}$ - statistic CR (1.553788) < t tabel (2.04227) dan nilai prob. $0.1307>0.05$ maka dapat disimpulkan bahwa variabel CR dalam penelitian ini tidak memiliki pengaruh terhadap IS.

Nilai t statistik ROA sebesar 0.895389 , sementara t tabel dengan tingkat $\mathfrak{a}=5 \%$ df $(n-k)=30$ didapat nilai $t$ tabel (2.04227). Dengan demikian t statistic ROA (0.895389) > (2.04227) dan nilai prob. $0.3772>$ 0.05 maka dapat disimpulkan bahwa ROA dalam penelitian ini tidak memiliki pengaruh terhadap IS. 
Nilai t statistic DER sebesar 3.422668, sementara t tabel tingkat $\mathfrak{a}=$ $5 \%$ df $(n-k)=30$ didapat nilai 2.04227. Dengan demikian t statistic DER (3.422668) > t tabel (2.04227) dan nilai prob.0.0018<0.05 maka dapat disimpulkan bahwa variabel DER dalam penelitian ini memiliki pengaruh terhadap IS.

\section{KESIMPULAN}

Berdasarkan hasil analisis dan pembahasan data, penulis memperoleh kesimpulan dari penelitian yakni, ukuran perusahaan berpengaruh negative terhadap income smoothing, NPM berengaruh terhadap IS, ROA tidak berpengaruh terhadap IS, CR tidak berpengaruh terhadap IS, dan DER berpengaruh terhadap IS. Dan sarannya penelitian berikutnya diharapkan dapat menambah jumlah sampel dan mewakili masing masing sektor industri sehingga hasilnya mampu menggambarkan secara menyeluruh keadaan perusahaan go public di Indonesia

\section{DAFTAR PUSTAKA}

Yasa, I. N. (2013). Perataan Laba serta faktor-faktor yang mempengaruhinya terdaftar di Bursa Efek Indonesia. 28.

Adi Utomo, W. P. (2018). Analisis pengaruh ukuran perusahaan,proftabilitas ,financial leverage,struktur menejerial dan net profit margin terhadap perataa laba (income smoothing)(studi kasus pada peusahaan manufaktur yang terdaftar di BEI). 48.

Bestivano, W. (2013). Pengaruh perusahaan,umur perusahaan,profitabilitas, dan leverage terhadap perataan laba pada perusahaan yang tedaftar di BEI. 25 .

Diastiti Okkarisma Dewi, T. H. (2010). Pengaruh jenis usaha,ukuran perusahaan,dan financial leverage terhadap tindakan perataan laba yang terdaftar di BEI . 28.

Eko Budi Santoso, S. N. Pengaruhprofitabilitas, financialleverage, dividen,ukuranperusahaan,k epemilikan institusional dan Kelompok usaha terhadap perataan laba studi kasus pada perusahaan non-financial yang tedaftar di BEI. 48.

Harris Prasetya, S. N. (2013). Pengaruh ukuran perusahaan ,profitabilitas,financial leverage,klasifikasi KAP dan likuiditas terhadap praktik perataan laba. 25.

Kris Brantas Abiprayu, I. R. (2011). Pengaruhprofitabilitas, ukuran perusahaan,dan financial leverage,kualitas audit dan dividend payout ratio terhadap perataan laba yang terdaftar di BEI tahun 2006-2009. 50 .

Sari, L. R. (2014). Pengaruh ukuran perusahaan dan struktur kepemilikan terhadap praktik perataan laba pada perusahaan manufaktur yang terdaftar di Bursa Efek Indonesia. 50. 
Sindi Retno Noviana, E. N. (2012). Analisis fakor-faktor yang mempengaruhi praktik perataan laba (studi empiris perusahaan manufaktur yang terdaftar di BEl periode 2006-2010. 25.

Susanto, H. d. (2008). Pengaruh struktur kepemilikan publik ,praktik pengelolaan perusahaan,jenisindustri,ukuran perusahan,profitabilitas dan tindakan peratan laba yang terdaftar di BEI. 45. 